$\left[\begin{array}{l}\text { Jpn. J. Toxicol. Environ. Health } \\ \text { 衛 } \\ 39\end{array}\right.$

\title{
綿繊維の酸触媒熱分解ガスクロマトグラフィーによる裁判化学的研究
}

\author{
竹腰裕二, $a$ 管野 進, ${ }^{a}$ 河瀬章司, ${ }^{a}$ 木方 $\quad$ 正, $\stackrel{b}{*}$ 鵜飼茂夫 $b$ \\ 岐皁県警察本部刑事部鑑識課科学捜查研究所, ${ }^{a}$ 岐皁薬科大学 ${ }^{b}$
}

\section{Forensic Chemical Study on Cotton by Acid-Catalyzed Pyrolysis-Gas Chromatography}

\author{
Yuzi Takekoshi, ${ }^{a}$ Susumu Kanno, ${ }^{a}$ Shozi Kawase, ${ }^{a}$ Tadashi Kino ${ }^{b}$ \\ and SHIGEO $\mathrm{UKAI}^{b}$ \\ Scientific Investigation Research Laboratory, Gifu Pref. Police H.Q., ${ }^{a} 1-1$ Yabuta, Gifu \\ 500, Japan and Gifu Pharmaceutical University, 5-6-1, Mitahora-higashi, \\ Gifu 502, Japan
}

(Received December 7, 1992)

It is known that the major products in the pyrolysis of cellulose can not be detected by gas chromatography because of their low volatility. Hence it has been difficult to analyze a slight amount of cotton composed of cellulose by pyrolysis-gas chromatography (PyGC).

In our study, acid-catalyzed pyrolysis was applied to forensic discrimination of cotton and its blended yarn by PyGC. Fibers were pyrolyzed using a Curie-point pyrolyzer, attached to gas chromatograph or gas chromatograph-mass spectrometer under the conditions by the addition of hydrochloric acid or phosphoric acid. The presence of acid during pyrolysis provided an increase of volatile products such as furfural, and elevated detection limit of the fibers by PyGC in comparison with the conventional methods. When $10 \%$ of hydrochloric acid or $20 \%$ of phosphoric acid was added, more furfural was detected.

This method made it possible to analyze a slight amount of cotton and its blended yarn by PyGC.

Keywords — acid-catalyzed pyrolysis-gas chromatography; cotton; blended yarn ; hydrochloric acid; phosphoric acid; furfural

\section{緒言}

近年，犯罪の悪質，巧妙化に伴い，指紋等の明白 な物的資料がそしくなってきていることから，犯罪 現場に遺留される微小，微細，微量な資料を積極的 に活用して科学的, 合理的な捜查を推進することが 不可欠となっている，なかでも繊維片は重要な情報 源として，その鑑定が増加している。

これまで緎維の一般的な鑑定法としては形態学的 検査法, ${ }^{1)}$ 染色及び溶剤による識別, ${ }^{2}$ 赤外分光分析 による成分検査 ${ }^{3)}$ などが行われている。一方，化学繊 維を含む高分子化合物の成分分析には熱分解ガスク ロマトグラフィー $(\mathrm{PyGC})^{3)}$ が有効な分析法として 沉用されている。
しかし，綿などのセルロース系繊維はセルロース の熱分解反応における主生成物がレボグルコサン, 3-デオキシグリコスロースなどの難揮発性物質であ $\eta$, 揮発性のフルフラール, レボグルコセノンの生 成量は極めて微量である4)ため, PyGCによってセ ルロース系繊維の裁判化学的検査を行うことは困難 である。

そこでセルロースのリン酸存在下での熱分解反応 においてはフルフラール，レボグルコセノンなどの 揮発性物質の生成量が増加すること占作着目し, 著 者らは, 各種の酸を用い綿絾維試料の酸触媒熱分解 ガスクロマトグラフィーについて基礎的な実験を 行った。

また，綿とポリエステルとの混紡の分析について 
も検討を行った。

\section{実験}

1. 実験材料綿繊維は岐阜県繊維試験場より 恵与されたものを用いた。また，綿とポリエステル との混紡は市販の綿 35\%，ポリエステル $65 \%$ と表示 されたもの（白衣）及び綿 50\%，ポリエステル $50 \%$ と表示されたもの（カッターシャツ）を用いた。塩 酸, リン酸, フルフラールなどの試薬は市販特級品 を用いた。 パイロホイルは日本分析製の $445^{\circ} \mathrm{C} ， 590$

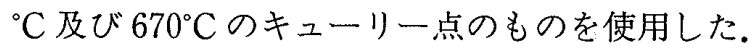

2. 装置及び測定条件 PyGC 並びに熱分解ガ スクロマトグラフー質量分析 (PyGC-MS) は Table Iに示す装置及び測定条件で行った。

3. 試験操作試料の繊維を各温度のキュー リ一点をもったパイロホイル上に置き，20\%リン酸 または $10 \%$ 塩酸 $1 \mu 1$ を添加し, 繊維を湿潤させ, 常 法に従いホイルを包み PyGC 及び PyGC-MSの試 料とした。

\section{結 果 及び考 察}

\section{1. 熱分解時に添加する各種酸の検討}

綿繊維のより糸約 $3 \mathrm{~mm}$ （重量約 $0.05 \mathrm{mg}$ ） 590 ${ }^{\circ} \mathrm{C}$ のパイロホイル上に置き， $1 ， 3 ， 5 ， 10 ， 20 \%$
の塩酸, リン酸, 硫酸, 硝酸, 酢酸の各種の酸水溶 液 $1 \mu 1$ を添加し繊維を湿潤させ，常法に従いパイロ ホイルを包み，熱分解ガスクロマトグラフィーを 行った結果, 硫酸, 硝酸, 醀酸を添加したものはい ずれの濃度においても綿の検出感度を上げるような 大きなピークは認められなかったが，塩酸及びリン 酸添加のパイログラムは Fig. 1 に示すように Rt 6.5 分付近のピーク 1 の生成量が増大し, さらに塩 酸添加時には Rt 7.7 分付近にピーク 2 , リン酸添加 時にはピーク 2 及び Rt 13.0 分付近にピーク 3 の生 成量の増大も認められ, 塩酸又はリン酸の添加に よって明らかに熱分解が促進されることが認められ た。

\section{2. 熱分解生成物の同定}

前記 1 で増大したピーク $1 ， 2 ， 3$ について 1 は GC-MSの EI 法において, $m / z 29,39,67,95,96$ (分 子イオンピーク)が, CI 法に打いて $m / z 97$ (擬分子 イオンピーク)がそれぞれ観測され, 既知フルフラー ルのマススペクトルと同一であったことからピーク 1 はフルフラールと同定した。また，ピーク 2 は EI 法において $m / z 27,53 ， 81 ， 110$ (分子イオンピー ク）が, CI 法において $m / z 111$ (擬分子イオンピー ク）がそれぞれ観測されたことから，Tsuchiya ${ }^{5)}$ が酸存在下でのセルロースの熱分解反応において，

Table I. PyGC and PyGC-MS Conditions

\begin{tabular}{ll}
\hline \hline Pyrolyzer & \\
Instrument & Japan Analytical Industry \\
& Curie point Model JHP-2(GC), JHP-3(GC-MS) \\
Pyrolysis & $445^{\circ} \mathrm{C}, 590^{\circ} \mathrm{C}, 670^{\circ} \mathrm{C} ; 3 \mathrm{~s}$ \\
Oven temp. & $130^{\circ} \mathrm{C}$ \\
Pipe temp. & $250^{\circ} \mathrm{C}$ \\
Sample weight & $0.05 \mathrm{mg}$ \\
GC & \\
Instrument & Shimadzu GC-7AG \\
Detector & FID \\
Column & $\mathrm{J} \& \mathrm{~W}$ DB-WAX $(0.25 \mathrm{~mm}$ i.d. $\times 15 \mathrm{~m})$, Film thickness $0.5 \mu \mathrm{m}$ \\
Column temp. & $80-230^{\circ} \mathrm{C}\left(10^{\circ} \mathrm{C} / \mathrm{min}\right)$ \\
Injection temp. & $250^{\circ} \mathrm{C}$ \\
Detector temp. & $250^{\circ} \mathrm{C}$ \\
Carrier gas & Nitrogen, Flow rate $0.91 \mathrm{ml} / \mathrm{min}, \mathrm{Split} 24: 1$ \\
GC-MS & \\
Instrument & Shimadzu QP-1000D \\
Column & $\mathrm{J} \mathrm{\&} \mathrm{W} \mathrm{DB-WAX}(0.25 \mathrm{~mm}$ i.d. $\times 15 \mathrm{~m})$, Film thickness $0.5 \mu \mathrm{m}$ \\
Column temp. & $80-230^{\circ} \mathrm{C}\left(10^{\circ} \mathrm{C} / \mathrm{min}\right)$ \\
Injection temp. & $250^{\circ} \mathrm{C}$ \\
Carrier gas & Helium, Flow rate $0.95 \mathrm{ml} / \mathrm{min}$ \\
Ion source energy & $70 \mathrm{eV}(\mathrm{EI}), 20 \mathrm{eV}(\mathrm{CI})$ \\
\hline
\end{tabular}


フルフラールとともにその生成量が増加することを 報告している5-メチルフルフラールと推定した。一 方, ピーク 3 は $\mathrm{EI}$ 法において $m / z 29,39,53,68$, 96，98が， CI 法において $m / z 127$ (擬分子イオン ピーク）がそれぞれ観測され，レボグルコセノンの

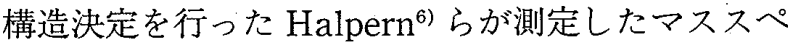
クトルと一致することから，レボグルコセノンと推 定した。

\section{3. 熱分解時に添加する酸の濃度の検討}

塩酸及びリン酸の濃度と熱分解生成物の影響をフ ルフラール（ピーク 1）の生成量を指標にして検討 した結果，Fig. 2 に示すように塩酸添加（塩酸触媒 法）の場合， $5 \%$ までは酸の濃度の上昇とともにフ
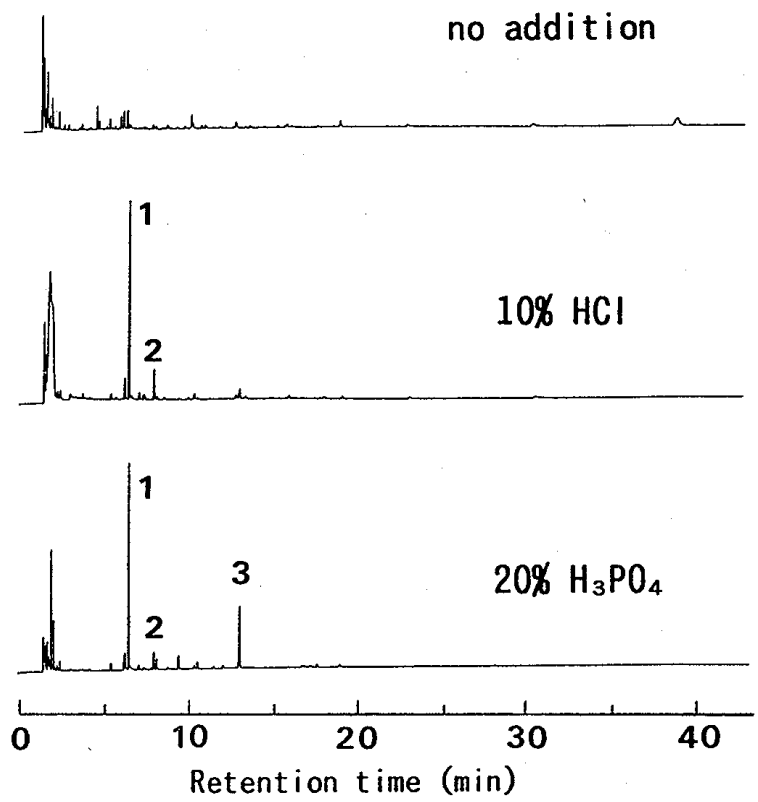

Fig. 1. Pyrograms of Cotton on Addition of Aqueous Acid and None at $590{ }^{\circ} \mathrm{C}$

Peak 1 : furfural, Peak 2 : 5-methyl furfural, Peak 3 : levoglucosenone.

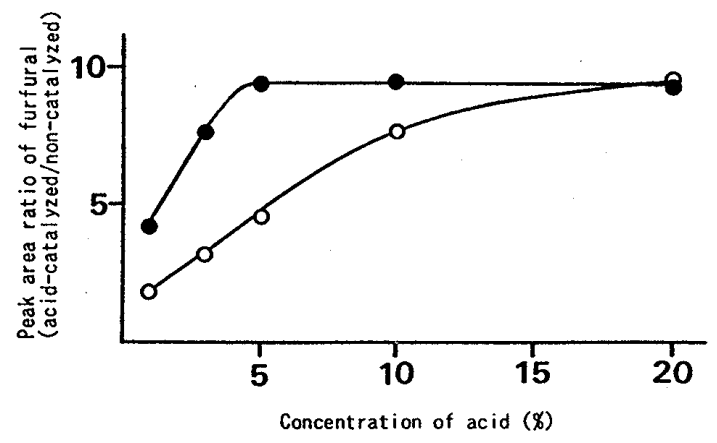

Fig. 2. Effects of Concentration of Acid on Yields of Furfural in Cotton Pyrolysis

: $\mathrm{HCl}$-catalyzed, $\bigcirc: \mathrm{H}_{3} \mathrm{PO}_{4}$-catalyzed.
ルフラールの生成量も増加したが，それ以降 $20 \%$ ま では濃度を変化させてもフルフラールの量に変化は 認められず通常の方法（酸を添加せず，綿繊維のみ で熱分解する方法）の約 9 倍の量で一定であった。

また，リン酸添加（リン酸触媒法）の場合，低濃 度では塩酸添加時に比べフルフラール量は少ない傾 向にあったが，濃度の上昇とともに増加し，20\%で は塩酸添加時の最高值に一致した。

一方，5-メチルフルフラールの生成量は酸濃度の 上昇とともにフルフラールの生成量とほぼ同様な増 加傾向が認められたが，レボグルコセノンの生成量 については，再現性にそしく酸濃度との関連は認め られなかった。

したがって, 本法で添加する酸の濃度は塩酸は $10 \%$ リン酸は $20 \%$ とした。

\section{4. 熱分解温度の検討}

綿緎維のより糸約 $3 \mathrm{~mm}$ について，常法，10\%嗑 酸触媒法，20\%リン酸触媒法の 3 種の方法により， それぞれ $445^{\circ} \mathrm{C}, 590^{\circ} \mathrm{C}, 670^{\circ} \mathrm{C}$ の熱分解温度で 3 秒間 熱分解ガスクロマトグラフィーを行い，得られたパ イログラムを比較し，それぞれの方法における熱分 解温度について検討したところ, Fig. $3,4,5$ に示す とおりであった。

常法（Fig. 3）においては，熱分解温度が高くなる にしたがって保持時間の早いピークは大きくなる が，いずれの温度においてもポリエステル繊維の場 合に観察される安息香酸，安息香酸ビニルのような 特徴的な大きなピークは認められなかった。

リン酸触媒法 (Fig. 4) においては，いずれの温度 においてもフルフラール, 5-メチルフルフラール, レ ボグルコセノンのピークの増大が認められた.なお，
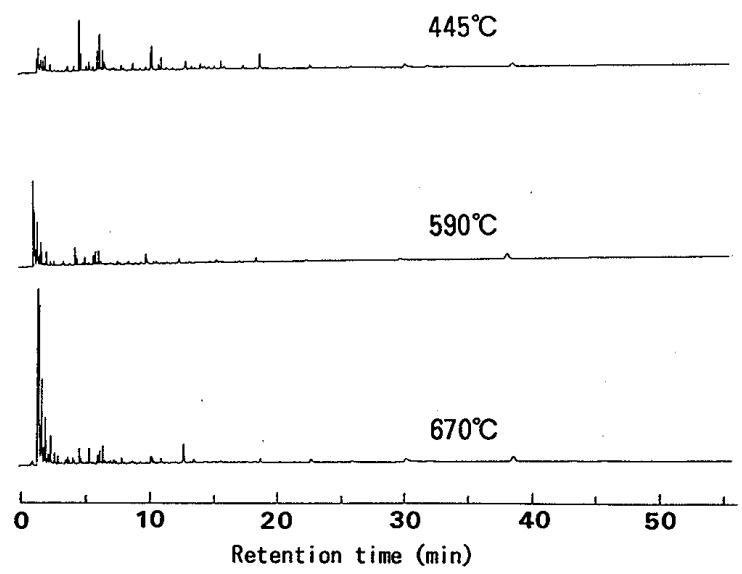

Fig. 3. Pyrograms of Cotton at Various Temperature 

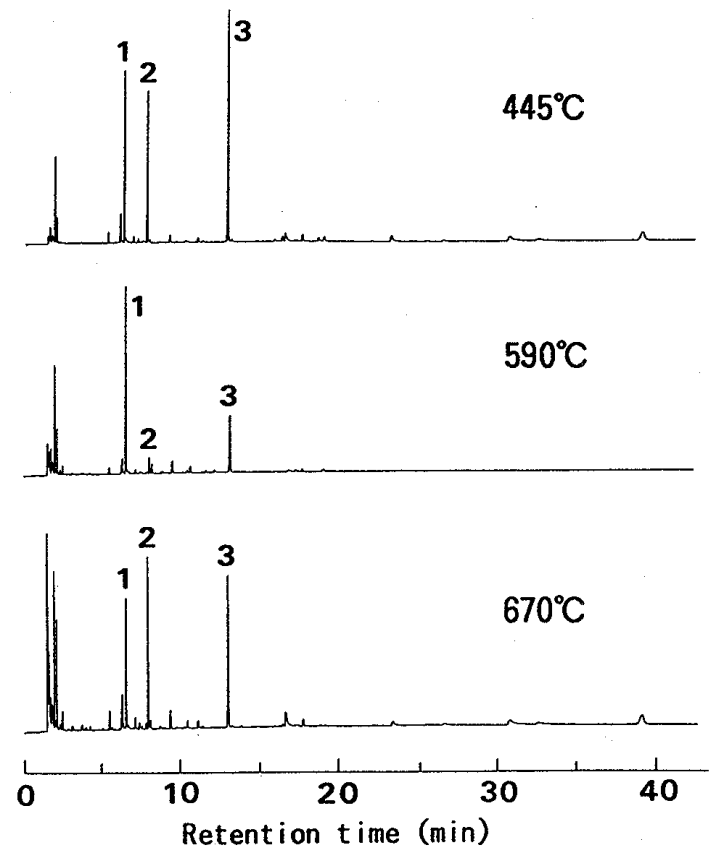

Fig. 4. Pyrograms of Cotton on Addition of $20 \%$ $\mathrm{H}_{3} \mathrm{PO}_{4}$ at Various Temperature
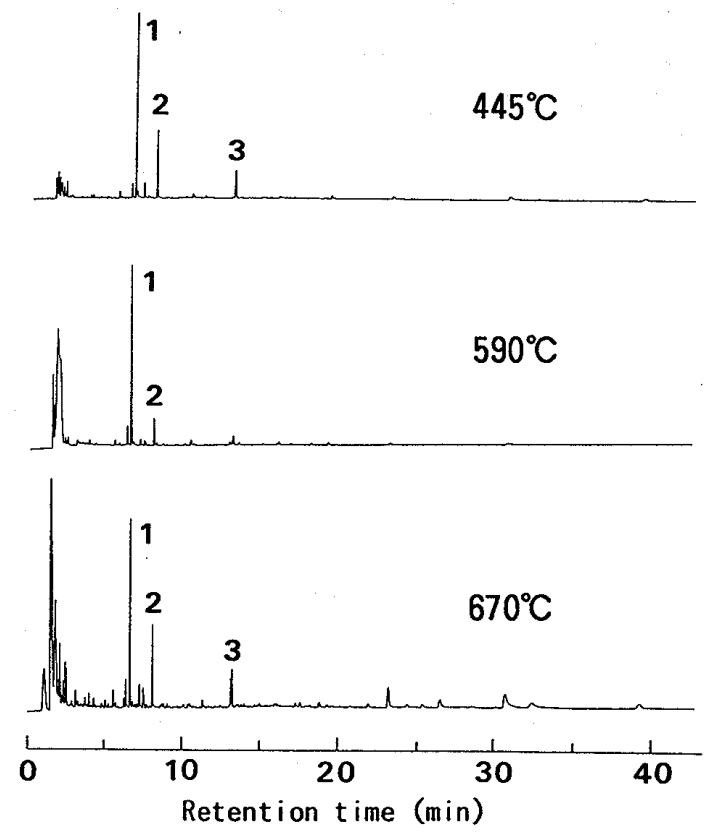

Fig. 5. Programs of Cotton on Addition of $10 \%$ $\mathrm{HCl}$ at Various Temperature

$445^{\circ} \mathrm{C}, 670^{\circ} \mathrm{C}$ の場合は 5-メチルフルフラール, レボ グルコセノンのピークもフルフラールのピークと同 程度までの增大が認められた。

塩酸触媒法（Fig. 5）においては，いずれの温度に おいても，フルフラール，5-×チルフルフラールの ピークの增大が認められた。なお， $445^{\circ} \mathrm{C}, 670^{\circ} \mathrm{C}$ の
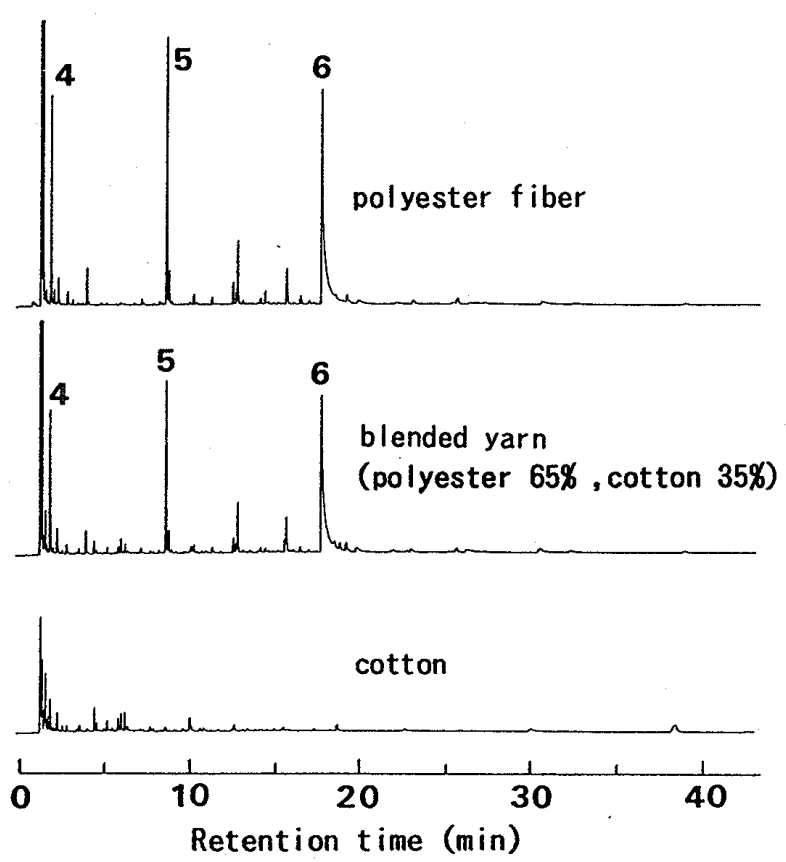

Fig. 6. Pyrograms of Polyester Fiber, Cotton and Blended Yarn at $590^{\circ} \mathrm{C}$

Peak 4 : benzene, Peak 5 : vinyl ester of benzoic acid, Peak 6 : benzoic acid.

場合はリン酸触媒法の場合と同様，レボグルコセノ ンのピークの増大も認められた。

このように両触媒法は常法に比較し，いずれの熱 分解温度においてもフルフラール生成量を顕著に増 大させることから，本法による綿繊維の分析は 445 ${ }^{\circ} \mathrm{C}, 590^{\circ} \mathrm{C}, 670^{\circ} \mathrm{C}$ のいすれれの熱分解温度においても 可能であることが判明した。

なお，5-メチルフルフラール，レボグルコセノンは $590^{\circ} \mathrm{C}$ の場合に比較し $445^{\circ} \mathrm{C}, 670^{\circ} \mathrm{C}$ の両温度におい て，やや大きなピークとして観察されたが，フルフ ラールが酸触媒法に扔けるセルロースの特異的熱分 解生成物であり，七ルロース系以外の綫維からの生 成は考えられないことから，セルロース系繊維の鑑 定には熱分解主生成物のフルフラールを指標とすれ ば十分とみなされる。そのため本法に扔ける熱分解 温度は, 纎維類の他にもゴム類, 紙類, 塗膜類など 多種多様なものの分析にPyGCを適用している裁 判化学の分野において一般的な $590^{\circ} \mathrm{C}$ とした。

\section{5. 混紡への適用}

常法により，ポリエステル $65 \%$ と綿 35\%の混紡，

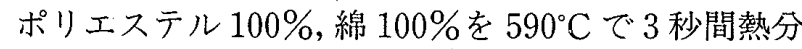
解し比較したところ，Fig. 6 に示すように混紡では Rt 6,7 分付近にポリエステル単独では見当らない ごく小さな綿由来と推定されるピークが認められ た.その他のピーク 4 は GC-MSの EI 法において 
$m / z 39,52,78$ (分子イオンピーク) が, CI 法にお いて $m / z 78,79$ (擬分子イオンピーク) が観測され るベンゼン, ピーク 5 は, EI 法において $m / z 51,77$, 105 が，CI 法において $m / z 149$ (擬分子イオンピー ク)が観測される安息香酸ビニル，ピーク 6 は EI 法 において $m / z 28,51,77,105,122$ (分子イオンピー ク）が，CI 法において $m / z 123$ (擬分子イオンピー ク）が観測される安息香酸などほとんどポリエステ ル由来7,8)のものであった：したがって，この結果か ら通常の PyGC(常法)によって混紡がポリエステル と綿より成るものであると判定することは困難で あった。

つぎに，本法のリン酸触媒法を混紡に適用したと ころ，Fig. 7 に示すようにポリエステルには見当ら ない綿由来のフルフラールのピークが Rt 6.5 分付 近に明らかに認められ，混紡がポリエステルと綿よ ク成るものであると判定することが可能となった。 また，同時に 5-メチルフルフラール，レボグルコセ ノンのピークも認められた。なお，ポリエステルの 熱分解生成物であるベンゼンと安息香酸ビニルの生 成量の減少も認められた。

さらに，本法の塩酸触媒法を混紡に適用したとこ ろ, Fig. 8 に示すようにリン酸触媒法の場合と同様, ポリエステルには見当らない綿由来のフルフラール

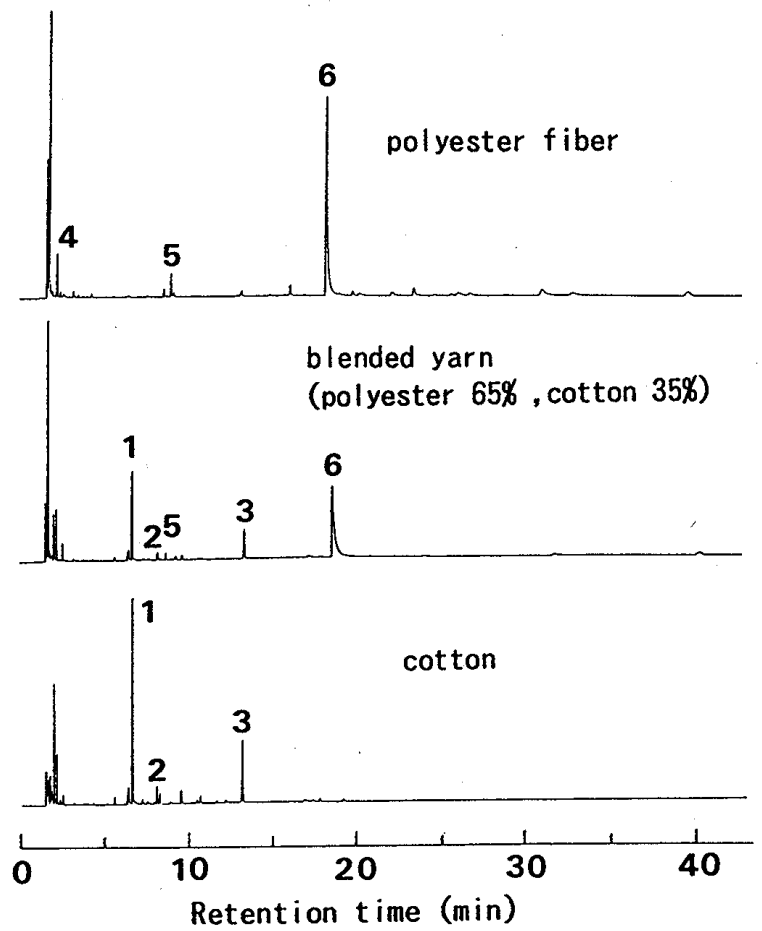

Fig. 7. Pyrograms of Polyester Fiber, Cotton and Blended Yarn on Addition of $20 \%$ $\mathrm{H}_{3} \mathrm{PO}_{4}$ at $590^{\circ} \mathrm{C}$
のピークが Rt 6.5 分付近に明らかに認められ, 混紡 がポリエステルと綿より成るものであると判定する ことが可能となった．また，同時に5-メチルフルフ ラールのピークも認められた。なお，ポリエステル の熱分解生成物である安息香酸ビニルの生成量の減 少とともに, 常法及びリン酸触媒法においては検出 されなかったピーク 7 及びピーク 8 が検出された。 GC-MSによりピーク 7 は EI 法において $m / z 38$, 51，77，112(分子イオンピーク)が，CI 法において $m / z 113$ (擬分子イオンピーク) が観測され, クロロ ベンゼンと推定された。また，ピーク 8 は EI 法にお いて $m / z 51,77,105,122$ が，CI 法において $m / z$ 185 (擬分子イオンピーク) が観測され, 安息香酸の クロロエチルエステルと推定された。

なお，市販カッターシャツ(ポリエステル/綿=50/ 50）についても本法により，ポリエステルと綿より 成るものであると判定することが可能であった。

\section{結語}

各種の酸を用い，微細な綿繊維試料の酸触媒熱分 解ガスクロマトグラフィーについて検討を行った。 綿繊維の酸触媒熱分解ガスクロマトグラフィーにお
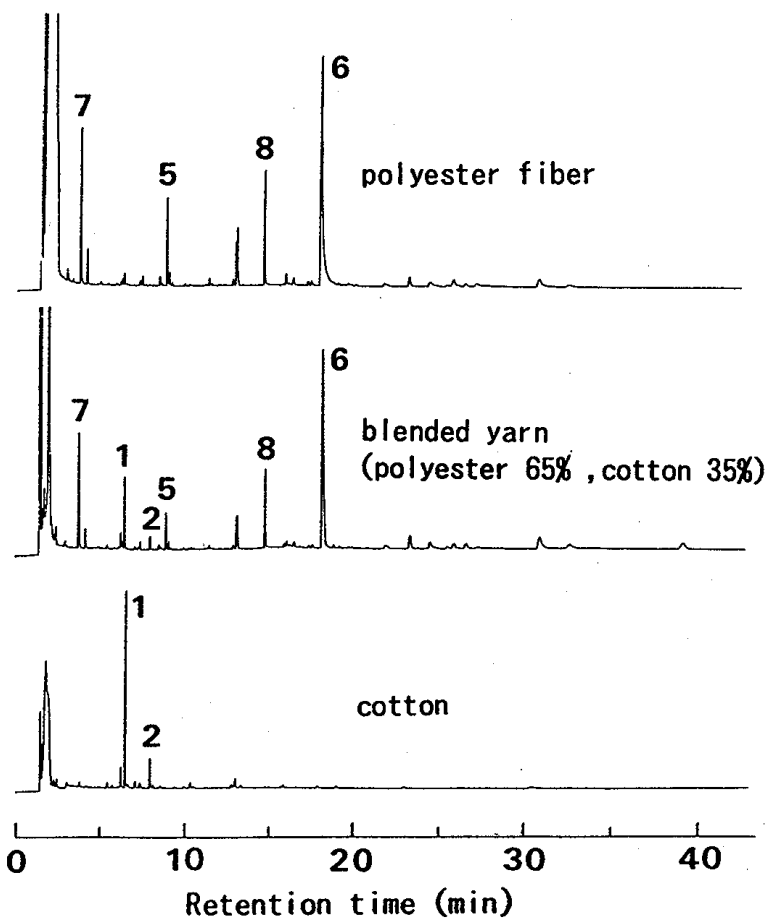

Fig. 8. Pyrograms of Polyester Fiber, Cotton and Blended Yarn on Addition of $10 \%$ $\mathrm{HCl}$ at $590^{\circ} \mathrm{C}$

Peak 7 : chlorobenzene, Peak 8 : chloroethyl ester of benzoic acid. 
いて，リン酸及び塩酸を添加することにより，七ル ロース系䋐維の特異的揮発性熱分解生成物であるフ ルフラールの生成量が増大し, そのピークの検出に より, 従来は困難であった微細な綿纎維及びその混 紡試料についても，熱分解ガスクロマトグラフィー により分析することが可能となった。

また，ポリエステルの塩酸触媒熱分解法において
は，常法及びリン酸触媒法の際には検出されなかっ たクロロベンゼン及び安息香酸クロロエチルエステ ルが生成することを明らかにした。

本法は試料に塩酸又はリン酸を添加する以外には 通常のPyGC と基本的に全く同じ操作であるため, 迅速簡便で微細なセルロース系瀻維及びその混紡の 分析には有効な方法である。

\section{引 用 文 献}

1）河合弘廸，田川高司，“図解繊維の形態，”繊維学会編，朝倉書店，東京，1989.

2）祖父江寛，“繊維便覧，原料編，”繊維学会編，丸善，東京，1988，pp.1026-1030.

3）宮坂啓象，“繊維・高分子測定法の技術，”繊維学会編，朝倉書店，東京，1985，pp.24-30.

4) A. Ohnishi, K. Kato, E. Takagi, Polymer J., 7, 431 (1975).

5) Y. Tsuchiya, K. Sumi, J. Appl. Polym. Sci., 14, 2003 (1970).

6) Y. Halpern, R. Riffer, A. Broido, J. Org. Chem., 38, 204 (1973).

7) 柘植 新, 分析化学, 35, 417 (1986).

8）平野治夫, 田中 昭, 科学警察研究所報告, 31, 172 (1978). 